\title{
Monitoring vegetation dynamics and carbon stock density in miombo woodlands
}

\author{
Natasha S Ribeiro ${ }^{1 *}$, Céu N Matos', Isabel R Moura², Robert A Washington-Allen ${ }^{3,4}$ and Ana I Ribeiro ${ }^{2}$
}

\begin{abstract}
Background: The United Nation's Program for Reducing Emissions from Deforestation and Forest Degradation (REDD+) aims to reduce the $20 \%$ contribution to global emissions of greenhouse gases from the forest sector, offering a financial value of the carbon stored in forests as an incentive for local communities. The pre-requisite for the setup of a participatory REDD + Program is the monitoring, reporting and verification (MRV) of baseline carbon stocks and their changes over time. In this study, we investigated miombo woodland's dynamics in terms of composition, structure and biomass over a 4-year period (2005-2009), and the Carbon Stock Density (CSD) for the year 2009. The study was conducted in the Niassa National Reserve (NNR) in northern Mozambique, which is the 14th largest protected area in the world.

Results: Mean tree density distributed across 79 species increased slightly between 2005 and 2009, respectively, from 548 to 587 trees ha ${ }^{-1}$. Julbernardia globiflora (Benth.) was the most important species in this area [importance value index $\left(\mathrm{IV}_{2005}=61\right.$ and $\left.\left.I \mathrm{VI}_{2009}=54\right)\right]$. The woodlands presented an inverted J-shaped diametric curve, with $69 \%$ of the individuals representing the young cohort. Woody biomass had a net increase of $3 \mathrm{Mg} \mathrm{ha}^{-1}$ with the highest growth observed in Dyplorhynchus condilocarpon (Müll.Arg.) Pichon ( $\left.0.54 \mathrm{Mg} \mathrm{ha}^{-1}\right)$. J. globiflora had a net decrease in biomass of $0.09 \mathrm{Mg} \mathrm{ha}^{-1}$. Total CSD density was estimated at ca. $67 \mathrm{MgC} \mathrm{ha}^{-1} \pm 24.85$ with soils (average $34.72 \pm 17.93 \mathrm{MgC} \mathrm{ha}^{-1}$ ) and woody vegetation (average $29.8 \mathrm{MgC} \mathrm{ha}^{-1} \pm 13.07$ ) representing the major carbon pools. The results point to a relatively stable ecosystem, but they call for the need to refocus management activities.

Conclusions: The miombo woodlands in NNR are representative of the woodlands in the eco-region in terms of vegetation structure and composition. They experienced net increase in woody biomass, a considerable recruitment level and low mortality. According to our results, NNR may present good potential for carbon sequestration especially in soils and woody biomass, representing an important potential carbon sink. However, further investigations are needed in order to address the contribution of this area to MRV REDD + initiatives.
\end{abstract}

Keywords: REDD+, Miombo woodlands, Carbon stock density, Conservation areas

\section{Background}

The United Nation's Program for Reduction in Emissions from Deforestation and Forest Degradation in Developing Countries (REDD+) aims to enhance the livelihoods of subsistence economies by facilitating the development of voluntary markets and international agreements to credit communities for afforestation and conservation of carbon activities [1,2]. The Intergovernmental Panel on Climate Change (IPCC) has provided guidelines on methodologies to assess carbon stocks [2-4]. Although remote sensing is

\footnotetext{
* Correspondence: joluci2000@yahoo.com

'Department of Forest Engineering, Eduardo Mondlane University, P.O. Box 257, Maputo, Mozambique

Full list of author information is available at the end of the article
}

a key tool to assess carbon stocks over large areas [1], operational field methods provide higher levels of accuracy and confidence $[3,4]$.

Tropical savannas and woodlands are a major component of the world's vegetation, covering $1 / 6$ of the land surface and over $1 / 2$ of the African continent. They account for about $30 \%$ of the primary production of all terrestrial vegetation, playing a crucial role in energy, water and carbon balance [5-10].

Miombo woodlands cover two-thirds of the SudanZambezian phytoregion (ca. 2.4 million $\mathrm{km}^{2}$ ) representing an important plant diversity center that extends over seven countries: Angola, the Democratic Republic of Congo, Malawi, Mozambique, Tanzania, Zambia and

\section{Biomed Central}


Zimbabwe [11]. Miombo is characterized by the overwhelming dominance of Brachystegia, Julbernardia and Isoberlina tree species, but its overall plant diversity is as high as 8,500 species including other tree, grass, herb and shrub species [12].

The structure and composition of miombo are strongly determined by their woody component, particularly by large trees, which play a key role in ecosystem function [13-15], primarily in nutrient cycling that accounts for a great deal of the carbon pool [16]. This component is in turn constrained by a combination of climate, disturbances [e.g. drought, fire, and herbivory primarily by elephants (Loxodonta africana Blumenbach)] and human activities [17-20]. There is increasing concern that the loss of mature trees in landscapes subjected to deforestation and degradation, as well as intense fires may result in the transformation of the woodlands into scrub or grasslands $[8,19,21-23]$ with the associated loss of biodiversity and biomass and thus an increase in carbon emissions.

Given the importance of the miombo woodlands as a reservoir of above- and below-ground carbon, it presents potential for implementation of REDD + policies towards environmental sustainability and socio-economic development [6-9]. However, research on carbon dynamics is still incipient (e.g. $[8,10]$ ) and it needs to be evaluated more systematically. Within this context, the purpose of this study was to conduct an IPCC Tier II [4] investigation of the change in vegetation dynamics in the miombo woodlands from the Niassa National Reserve (NNR) in order to 1) explore the woodland's dynamics in terms of structure, composition and biomass between 2005 and 2009; and 2) estimate the ecosystem carbon stock density (CSD) for the year 2009. NNR is one of the most pristine conservation areas of miombo woodlands in southern Africa and is probably a large repository of carbon, thus representing a key conservation area for MRV REDD + initiatives [24-26].

\section{Results}

Woodland dynamics in 4 years: structure, composition and biomass

A total of 1933 individuals (548 trees ha-1) belonging to 79 tree species were recorded in 2005 and a total of 1990 individuals (587 trees ha-1) were recorded in 2009. In both years, the top 11 ecologically important tree species, expressed by the importance value index (IVI), were: Julbernardia globiflora $\left(\mathrm{IVI}_{2005}=61\right.$ and $\left.\mathrm{IVI}_{2009}=54\right)$, Diplorhynchus condylocarpon $\left(\mathrm{IVI}_{2005}=22\right.$ and $\mathrm{IVI}_{2009}=$ 23), Brachystegia boehmii Taub. $\left(\mathrm{IVI}_{2005}=12\right.$ and $\mathrm{IVI}_{2009}=22$ ), Pseudolachnostylis maprouneifolia Pax. var. maprouneifolia (IVI = 17 in both years), Sclerocarya birrea (A. Rich.) Hochst. (IVI = 17 in both years), Burkea africana Hook. (IVI = 13 in both years), Brachystegia allenii Burtt Davy \& Hutch. (IVI = 12 in both years), Diospyros kirkii Hiern $\left(\mathrm{IVI}_{2005}=14\right.$ and $\mathrm{IVI}_{2009}=10$ ), Brachystegia manga De Wild. (IVI = 10 in both years), Pterocarpus angolensis DC. $\left(\mathrm{IVI}_{2005}=11\right.$ and $\left.\mathrm{IVI}_{2009}=9\right)$ and Terminalia stenostachya Engl. \& Diels (IVI $=7$ in both years) (Figure 1). Altogether, these species accounted for $65 \%$ of the total IVI in both years. Other ecologically important species found in this study were Combretum hereroense Schinz (IVI $=5$ in both years), Catunaregam spinosa (Thunb) Tirveng (IVI = 5 in both years), Combretum zeyheri Sond. $\left(\mathrm{IVI}_{2005}=5\right.$ and $\left.\mathrm{IVI}_{2009}=4\right)$, among others. At the natural regeneration level we found 55 species that were not present in the adult stage and 48 species also present in the adult classes.

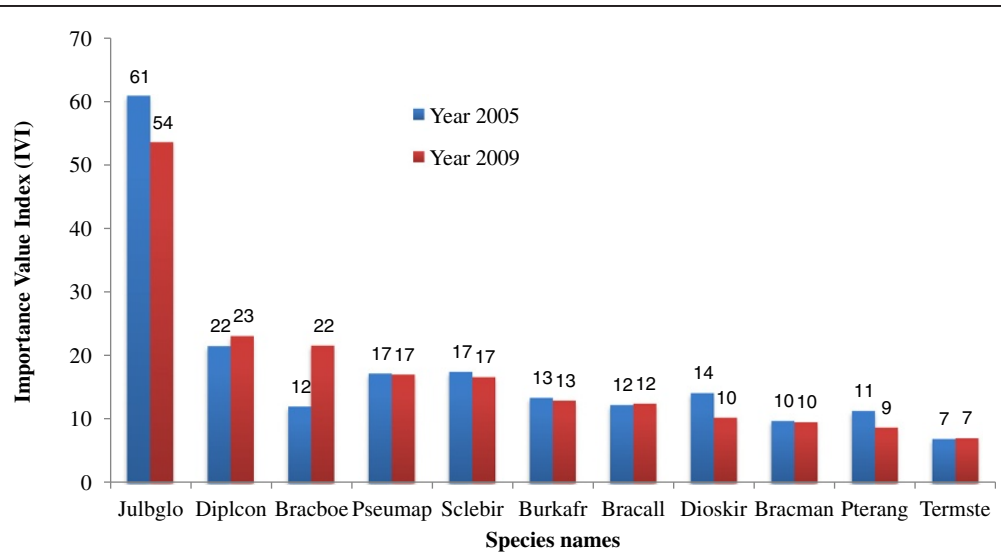

Figure 1 Importance Value Index (IVI) by species in 2005 and 2009. Legend: Julbglo (Julbernardia globiflora); Diplcon (Diplorhynchus condilocarpon); Bracboe (Brachystegia boehmii); Pseumap (Pseudolachnostylis maprouneifolia); Sclebir (Sclerocarya birrea); Burkafr (Burkea africana); Bracall (B. allenii); Dioskir (Diospyros kirkii); Bracman (B. manga); Pterang (Pterocarpus angolensis); Termste (Terminalia stenostachya). 
Horizontal structure measured as the diametric distribution was typical of tropical and sub-tropical forests with an inversed J-shape diametric curve. In both years $69 \%$ of the individuals were represented in the young cohort (diameter at breast height - dbh: 5-15-cm), while only $0.55 \%$ of individuals were represented in the adult class (> 45-cm of dbh). Vertical structure indicated two tree strata with a mean dominant height of 8-m (varying from 5 to $22-\mathrm{m}$ ). Nearly $80 \%$ of the trees were established in the sub-canopy stratum (between 7 and 10.5-m) and only $11 \%$ were represented in the upperstorey (height above 19-m). The lower stratum was basically composed of grass and herbaceous species.

The total woody biomass estimated in 2009 was $59 \mathrm{Mg} \mathrm{ha}^{-1} \pm 26.15$ (ranging from 15 to $165 \mathrm{Mg} \mathrm{ha}^{-1}$ ), which represents an increase in biomass of $3 \mathrm{Mg} \mathrm{ha}^{-1}$ (or 5\%) in 4 years. Seventy six percent of the 25 most abundant species presented a net growth of biomass ranging from 0.01 to $0.54 \mathrm{Mg} \mathrm{ha}^{-1}$, while $24 \%$ had a negative net growth (Table 1 for the top 10 species). The highest growth was observed for $D$. condylocarpon (0.54 $\left.\mathrm{Mg} \mathrm{ha}^{-1}\right)$, followed by B. allenii $\left(0.40 \mathrm{Mg} \mathrm{ha}^{-1}\right)$, $P$. maprouneifolia $\left(0.29 \mathrm{Mg} \mathrm{ha}^{-1}\right)$ and $B$. africana (0.25 Mg ha $\left.\mathrm{Mg}^{-1}\right)$. Other ecologically important species such as B. boehmii (0.11 Mg ha $\left.{ }^{-1}\right)$ and $T$. stenostachya (0.14 $\mathrm{Mg} \mathrm{ha}^{-1}$ ) experienced smaller net biomass growth, while $J$. globiflora experienced a negative net biomass of $-0.09 \mathrm{Mg} \mathrm{ha}^{1}$.

Biomass of recruiting individuals (those entering the diametric class of $5 \mathrm{~cm}$ in 2009) varied between 0 and $0.28 \mathrm{Mg} \mathrm{ha}^{-1}$. B. boehmii presented the most prominent recruitment $\left(0.28 \mathrm{Mg} \mathrm{ha}^{-1}\right)$, followed by $D$. condylocarpon (0.23 $\left.\mathrm{Mg} \mathrm{ha}^{-1}\right)$, Brachystegia spiciformis Benth. (0.19 $\left.\mathrm{Mg} \mathrm{ha}^{-1}\right)$, P. maprouneifolia (0.13 $\mathrm{Mg} \mathrm{ha}^{-1}$ ) and $B$. allenii $\left(0.13 \mathrm{Mg} \mathrm{ha}^{-1}\right)$. The rest of the species presented less than $0.1 \mathrm{Mg} \mathrm{ha}^{-1}$ of ingrowth.
Mortality was in general very low for most tree species, varying between 0 and $0.22 \mathrm{Mg} \mathrm{ha}^{-1}$. J. globiflora presented the highest mortality of $0.22 \mathrm{Mg} \mathrm{ha}^{-1}$, followed by $P$. angolensis and $B$. spiciformis (both with ca. $0.055 \mathrm{Mg} \mathrm{ha}^{-1}$ ).

\section{Ecosystem carbon stock density}

The estimated Carbon Stock Density (CDS) for the year 2009 was used in this study as the reference data, given that it represents the most updated and complete (above and belowground) estimation as compared to the data from 2005. The total CSD estimated for this area was 67 $\mathrm{MgC} \mathrm{ha}^{-1}$ (Stdev \pm 24.85$)$. The major contributors to the CSD were soils and woody vegetation. The former represented ca. $52 \%$ (average 34.72; Stdev $\pm 17.93 \mathrm{MgC}$ $\mathrm{ha}^{-1}$ ) of the total CSD, ranging from 8 to $89.8 \mathrm{MgC} \mathrm{ha}^{-1}$ and the latter corresponded to ca. $45 \%$ of the total CSD (average 29.88; Stdev $\pm 13.07 \mathrm{MgC} \mathrm{ha}^{-1}$ ), varying from 10 to $79.7 \mathrm{MgC} \mathrm{ha}^{-1}$ (Table 2). The error estimation was 7.14, indicating 90\% level of precision. J. globiflora had the greatest contribution with $9 \mathrm{MgC} \mathrm{ha}^{-1}$, followed by P. maprouneifolia, B. africana, B. boehmii and B. manga with contributions ranging from 1 to $3 \mathrm{MgC} \mathrm{ha}^{-1}$.

\section{Discussion}

This study presents the dynamics of miombo woodlands over a 4-year growth period and ecosystem carbon stock density (CSD) for the year 2009 in 50 permanent sample plots across NNR. It is unlikely that the analyses reveal all the existing variations within the area given its large extension $\left(42,000 \mathrm{~km}^{2}\right)$, the short period of time of this study (4-years), the low representative sampling effort and the limited accessibility of the area. However, the results are in sequence of previous studies conducted by the authors and collaborators [8,19,24,27], which together show consistent ecological patterns.

Table 1 Biomass stocks, mortality and net biomass changes for the 10 most dynamic tree species in Niassa National Reserve

\begin{tabular}{|c|c|c|c|c|}
\hline Species name & $\begin{array}{c}\text { Biomass } 2005 \\
\left(\mathrm{Mg} \mathrm{ha}^{-1}\right) \pm \text { Stdev }\end{array}$ & $\begin{array}{c}\text { Biomass } 2009 \\
\left(\mathrm{Mg} \mathrm{ha}^{-1}\right) \pm \text { Stdev }\end{array}$ & $\begin{array}{c}\text { Mortality } \\
\left(\mathrm{Mg} \mathrm{h}^{-1}\right) \pm \text { Stdev }\end{array}$ & $\begin{array}{c}\text { Net biomass changes } \\
\left(\mathrm{Mg} \mathrm{ha}^{-1}\right)\end{array}$ \\
\hline Diplorhynchus condilocarpon & $1.82 \pm 0.8$ & $2.38 \pm 0.85$ & $0.02 \pm 0.01$ & 0.54 \\
\hline Brachystegia allenii & $3.26 \pm 1.02$ & $3.70 \pm 1.03$ & $0.04 \pm 0.01$ & 0.40 \\
\hline Burkea africana & $3.08 \pm 1.01$ & $3.33 \pm 1.00$ & 0.00 & 0.25 \\
\hline Pseudolachnostylis maprouneifolia & $2.42 \pm 0.85$ & $2.73 \pm 0.80$ & $0.02 \pm 0.01$ & 0.29 \\
\hline Terminalia stenostachya & $0.63 \pm 0.3$ & $0.78 \pm 0.31$ & $0.01 \pm 0.005$ & 0.14 \\
\hline Brachystegia boehmii & $5.83 \pm 1.2$ & $5.96 \pm 1.12$ & $0.02 \pm 0.01$ & 0.11 \\
\hline Dyospiros kirkii & $1.30 \pm 0.95$ & $1.39 \pm 0.90$ & 0.00 & 0.09 \\
\hline Combretum hereroense & $0.48 \pm 0.02$ & $0.53 \pm 0.01$ & $0.02 \pm 0.01$ & 0.03 \\
\hline Julbernardia globiflora & $1.44 \pm 0.75$ & $1.57 \pm 0.73$ & $0.22 \pm 0.015$ & -0.09 \\
\hline Pterocarpus angolensis & $2.18 \pm 1.20$ & $1.88 \pm 1.19$ & $0.06 \pm 0.01$ & -0.36 \\
\hline
\end{tabular}


Table 2 Carbon Stock Density (CSD) of miombo woodlands in Niassa National Reserve

\begin{tabular}{lcccccc}
\hline Ecosystem Compartment (EC) & Biomass $\left(\mathbf{M g ~ h a}^{-\mathbf{1}}\right)$ & Stdev & Carbon Sotck Density (CSD) $\left(\mathbf{M g C ~ h a ~}^{-\mathbf{1}}\right)$ & Stdev & SE & \% of total CSD \\
\hline Trees & 59.00 & 26.15 & 29.88 & 13.07 & 0.26 & 45 \\
Dead Trees & 0.12 & 0.37 & 0.06 & 0.19 & 0.003 & - \\
Grasses & 4.05 & 1.78 & 2.03 & 0.89 & 0.018 & 3 \\
Litter & 0.12 & 0.06 & 0.06 & 0.03 & 0.001 & - \\
Herbaceous & 0.04 & 0.03 & 0.02 & 0.01 & 0.0002 \\
Soil & - & - & 34.72 & 17.93 & 0.36 & - \\
Total & 63.33 & 28.00 & 66.77 & 24.85 & 0.28 & 100 \\
\hline
\end{tabular}

\section{Woodlands dynamics over the 4-year study period (2005-2009)}

Structure and species composition of the woodlands reveal a typical miombo ecosystem, dominated by Julbernardia globiflora, Brachystegia boehmii, Pseudolachnostylis maprouneifolia, Diplorhynchus condylocarpon and Burkea africana. Tree density and woody biomass presented a concomitant increase, respectively 57 ind. ha ${ }^{-1}$ (i.e. 3\%) and $3 \mathrm{Mg}$. ha ${ }^{-1}$ (i.e. 5\%) in 4 years. At the species level, both parameters were also concurrent, i.e. biomass accumulation accompanied species ecological expression. For example, D. condilocarpon was the most prominent species in biomass growth and had an increase in IVI from 22 to 23, while J. globiflora experienced negative net biomass growth (due to low biomass recruitment and high mortality) and had a decrease in IVI from 61 to 54 . Our results indicate that the woodlands in NNR were dynamic and presented a trend that is within the range found elsewhere in the miombo eco-region (380 to 1,400 trees $\mathrm{ha}^{-1}$ and more than 50 species) [19,28-37].

The horizontal and vertical structures were stable over the 4-year study period. The woodland had a healthy size-class distribution with a higher number of juvenile trees $(5-15 \mathrm{~cm} \mathrm{dbh})$ than adults $(>45 \mathrm{dbh})$. This structure is commonly found across the miombo region and is usually an expression of the dominant canopy of Caesalpinoideae trees [12]. However, the dominant height found in this study $(8 \mathrm{~m})$ is lower than expected for dry miombo $(10-15 \mathrm{~m})[38,39]$. This may be explained by a combination of factors such as poor soils, climatic conditions and disturbances $[8,12,19,27]$. It is well known that miombo soils are in general nutrient-poor and NNR is not an exception. For example [40], notes that in drier places (with shallow soils or with less soil moisture storage capacity) of the reserve the woodland is shorter and more open.

Disturbances, especially fires and elephants, are also important factors in shaping the ecosystem structure and composition, creating a woodland of lower density and stature at some places of NNR $[8,12,19,27,41]$. Elephants uproot and de-branch large trees promoting the grass component, which feeds late dry-season fires. The latter shapes the ecosystem by removing saplings and young individuals of specific tree species.

The fact that the biomass and ecological expression of J. globiflora has decreased from 2005 to 2009 may also be an indication of the influence of fires, since it is known that this species is fire-sensitive and tends to decline under regular burnings [12]. Furthermore, J. globiflora along with others species in NNR are influenced by human land management practices. For example, local communities use some tree species, such as J. globiflora, for several purposes including bark-based beehives, timber production, food or medical applications (N. Ribeiro, unpublished results).

\section{Carbon stock density (CSD)}

Estimation of CSD is a basic step in carbon accounting and consideration of land use options and strategies to promote carbon sequestration. Benchmark sites are vital as they allow determination of deviations under different land uses. This is particularly important in the miombo eco-region in which the diversity of soils, climate, hydrology and disturbances return highly variable CSDs making a comparison among sites not always possible $[9,42]$. In fact, CSD values in NNR ranged from 10 to 80 $\mathrm{MgC} \mathrm{ha}{ }^{-1}$ among sampling plots, which may be attributed to its large extension of $42,000 \mathrm{Km}^{2}$ and associated variation in environmental conditions including fire frequency and elephant density [12].

Overall the mean CSD of ca. $67 \mathrm{MgC} \mathrm{ha}^{-1}$ (Stdev \pm 26.15) and a woody vegetation CSD of ca. $30 \mathrm{Mg} \mathrm{C} \mathrm{ha}^{-1}$ (Sdev $\pm 13.07 ; 45 \%$ of the total CSD in NNR) were slightly higher when compared with other studies in the miombo eco-region (Table 3) and comparable to the estimations of Ribeiro et al. [8] conducted in the same area $\left(35 \mathrm{MgC} \mathrm{ha}^{-1}\right)$. The total precision of $11 \%$ indicates that the estimations in this study were within the precision range (10-20\%) required for this type of analysis $[43,44]$. J. globiflora is a major contributor to the ecosystem's CSD representing $30 \%$ of woody CSD and $13 \%$ of the total CSD. As discussed previously in this paper, the species dominates the area but its ecological value and biomass decreased in 4 years (IVI decreased from 61 
Table 3 Comparative results of carbon stock density with other similar studies across the miombo eco-region

\begin{tabular}{|c|c|c|c|c|}
\hline Ecosystem compartment & This study (Mg C ha ${ }^{-1}$ ) & Other studies $\left(\mathrm{Mg} \mathrm{C} \mathrm{ha}^{-1}\right)$ & Localization & Reference \\
\hline \multirow[t]{2}{*}{ Soil } & $34.72 \pm 17.93$ & 57.90 & Gorongosa, Mozambique & [9] \\
\hline & & 31.04 & Dombe, Manica, Mozambique & {$[45]$} \\
\hline \multirow[t]{5}{*}{ Trees } & $29.88 \pm 13.07$ & $19 \pm 8$ & Gorongosa, Mozambique & [9] \\
\hline & & $13.17-32.10$ & Beira Corridor, Mozambique & [46] \\
\hline & & 20.88 & Niassa, Mozambique & Sitoe, Unpublished data \\
\hline & & 26.48 & Dombe, Manica, Mozambique & {$[45]$} \\
\hline & & 35.00 & Niassa National Reserve & {$[8]$} \\
\hline \multirow[t]{2}{*}{ Grasses } & $2.03 \pm 0.89$ & 1.2 & Niassa, Mozambique & Sitoe, Unpublished data \\
\hline & & 0.65 & Dombe, Manica, Mozambique & {$[45]$} \\
\hline \multirow[t]{2}{*}{ Litter } & $0.06 \pm 0.03$ & 0.8 & Niassa, Mozambique & Sitoe, Unpublished data \\
\hline & & 3.0 & Dombe, Manica, Mozambique & [45] \\
\hline Dead Trees & $0.06 \pm 0.19$ & - & - & - \\
\hline Herbaceous & $0.02 \pm 0.01$ & $0.55 \pm 0.02$ & Eastern Arc Mountains, Tanzania & [42] \\
\hline Total carbon & $10.13-79.69$ & $13-30$ & Eastern Arc Mountains, Tanzania & [42] \\
\hline
\end{tabular}

to 54) likely as a result of a combined result of fires and human land management practices. This points to the need to refocus management activities in NNR to prioritize human land management practices, especially fires. Otherwise major changes may be imposed on this ecosystem, which in turn may lead to a decrease in CSD especially of dominant species such as J. globiflora.

CSD in the first $30 \mathrm{~cm}$ of soil represents the major carbon pool in this area as expected for the miombo ecosystem $[9,45,47]$. Soil carbon in miombo woodlands is not widely studied and reported. However, a few studies indicate that the conversion of miombo woodlands to short-duration croplands is a major cause of carbon release from soils in the region $[43,45,48]$. As stated previously [27] fires are a major ecological factor in the reserve but their influence on soil CSD is a matter of further investigation and questions of how to improve soil CSD by managing fire may be of interest.

Although our CSD estimates are not representative of the entire NNR (for the reasons described above), the added value of this study in the context of REDD + lies in the fact that it gives an overview of CSD and carbon pools in this area. The results revealed that at the current level of management (more focused on wildlife and less on vegetation, fires and human activities) NNR can still be considered an important spot for carbon markets. Further estimations would be necessary in order to contribute to the national MRV REDD + initiatives. Those should include among others, the development of local allometric equations, and systematic and extensive carbon estimations by increasing the sampling effort and calibration of high-resolution remote sensing data. What constitutes the appropriate management approach in terms of REDD + will have to be determined in consultation with local communities, NNR managers as well as forest authorities. One major limitation would be the limited capacity of local communities in establishing partnerships. However, the experiences of benefit sharing through devolution of $20 \%$ of the conservation fees appear to be a good starting point to involve communities in forest management.

\section{Conclusions}

Our study revealed that the miombo woodlands in NNR are a good representation of miombo woodlands in the region. Species composition and structure followed the trend in the eco-region with dominance of typical miombo tree species. In 4 years the ecosystem experienced a slight increase in woody biomass, a considerable recruitment level and low mortality. However, one of the most important species - Julbernardia globiflora - showed a decrease in IVI and in biomass. This may indicate that the species is under pressure given its relative importance for local livelihoods and low tolerance to fires.

NNR presents good potential for carbon sequestration especially in soils and woody biomass. Even though our results may not be representative of the entire area, they represent a useful benchmark against which other estimates can be compared. Further and more accurate carbon estimates need to be performed to accurately account for carbon in the area, before a decision is made on engaging in REDD + initiatives.

Overall, the authors recommend that management activities and practices in NNR focus on fire management and human land-use practices. These would include among other things defining a concrete communitybased fire management program and engage local communities in sustainable forest management activities. 


\section{Methods}

\section{Study site}

This study was conducted in Niassa National Reserve (NNR), a $42,000 \mathrm{~km}^{2}$ conservation area that is located in northern Mozambique between $12^{\circ} 38^{\prime} 48.67^{\prime \prime} \mathrm{S}$ and $11^{\circ} 27^{\prime} 05.83^{\prime \prime} \mathrm{S}$ and $36^{\circ} 25^{\prime} 21.16^{\prime \prime} \mathrm{E}$ and $38^{\circ} 30^{\prime} 23.74^{\prime \prime} \mathrm{E}$ $[8,19,49,50]$ (Figure 2).

The climate is tropical sub-humid, with a mean annual precipitation (MAP) of $900-\mathrm{mm}$ that increases from the east $(800-\mathrm{mm})$ to the west $(1,200-\mathrm{mm})$ and a mean annual temperature (MAT) of $25^{\circ} \mathrm{C}$ that ranges from 20 to $26^{\circ} \mathrm{C}$ during the dry season (May - October). The wet season (November - April) has a MAP of $900-\mathrm{mm}$ and a MAT of $30^{\circ} \mathrm{C}$. NNR has a gently undulating landscape on a plateau with elevations ranging from 300 to $600-\mathrm{m}$ above-sea-level (asl).

According to White [51], NNR is classified as "drier Zambezian miombo woodland" with intrusions of east African coastal elements along the Rovuma and Lugenda rivers. Ribeiro et al. [8] determined that $82 \%$ of the reserve is miombo woodland. Low and medium-density woodlands occupy the lowland areas. High-density woodlands are located on the slopes of the Mecula and Jao inselbergs in the central portion of the reserve, and along the mainstreams in the form of riverine forests.
This study was conducted in the lowland miombo woodlands.

The woodlands in NNR are floristically poorer than the wet miombo and are dominated by the presence of Brachystegia spiciformis, Brachystegia boehmii and Julbernardia globiflora [12]. Other ecologically important species in the area are: Pseudolachnostylis maprouneifolia, Pterocarpus angolensis and Diplorhynchus condylocarpon. Combretum spp. in the east and Uapaca spp. in the west are also present in NNR [19]. The canopy is generally less than $15-\mathrm{m}$ in height and the trees are deciduous for a month or more during the dry season.

\section{Data acquisition}

Field sampling was conducted in 2 years (2005 and 2009) according to the methods reported in [19]. Fifty 30-m diameter circular plots were established in July 2004 and measured in 2005 and 2009. Each plot was geographically referenced using a Geographic Positioning System (GPS) unit (Garmin III +, Garmin Inc.). Individual species were identified according to [52] and [53]. Diameter-at-breast height (dbh), height, and ingrowth were measured for all trees with dbh $>5-\mathrm{cm}$ in July 2005 and July 2009. Ingrowth was considered as all the individuals entering the $5-\mathrm{cm}$ dbh size class by 2009. Every individual of the

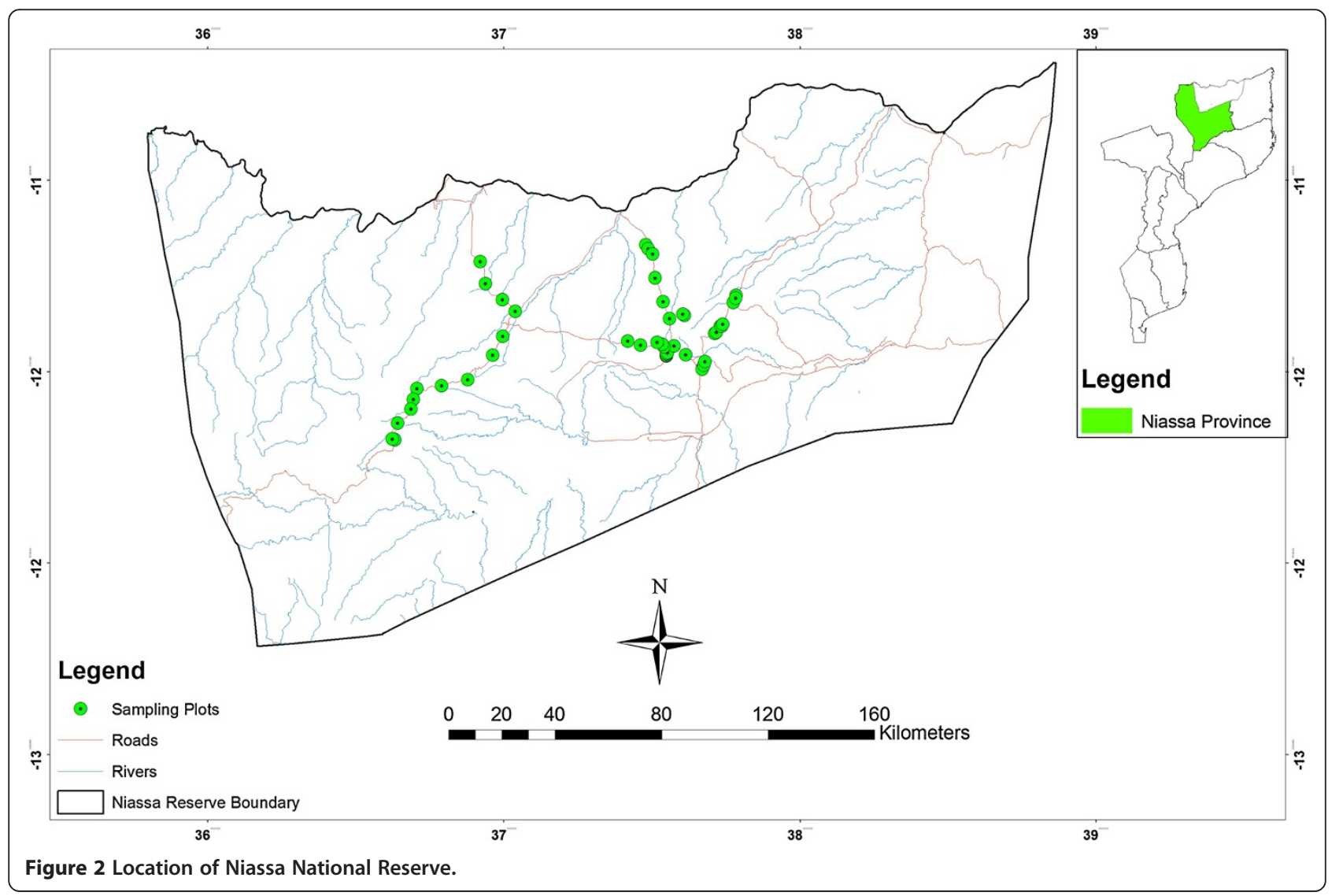


ingrowth cohort was measured for $\mathrm{dbh}$ and height in 2009. Mortality was measured in each plot as the number of individuals found dead during the study period. Natural regeneration was measured by the number of individuals with $\mathrm{dbh}<5-\mathrm{cm}$ and height between 0.3 and 1-m. Grass biomass was measured in 2005 and 2009 along two transects within every plot, using the Disc Pasture Meter (DPM) developed by Bransby and Tainton [54] for African savannas and calibrated for the miombo woodlands in southern Africa. Litter and herbaceous biomass were estimated by collecting 15 samples of each component in every plot, weighting them for green weight $(\mathrm{kg})$ and drying until constant weight in a Labcon, EFDO kiln at $105^{\circ} \mathrm{C}$.

Twelve soil samples per plot at 0 to $30 \mathrm{~cm}$ depth were analyzed for carbon and bulk density using the WalkleyBlack method [55].

\section{Data analysis}

To achieve a nearly complete description of species composition and distribution this study used the importance value index - IVI [56]. IVI was calculated by adding up three characteristics of a particular species: relative frequency (how often a species occurs in the plots), relative abundance (density of plants) and relative dominance [density of stock expressed as basal area, calculated from Eq. (2)]. Thus, the IVI is an indicator of ecosystem importance and is frequently used as a quantifier for vegetation studies. Stock density was calculated as:

$$
\mathrm{BA}=(\pi / 40000) \times\left(d b h^{2} / \mathrm{a}\right)
$$

Where $\mathrm{BA}=$ basal area $\left(\mathrm{m}^{2} \mathrm{ha}^{-1}\right), \mathrm{dbh}=$ diameter at breast height and $a=$ area of a plot $(=0.071 \mathrm{ha})$.

Tree species biomass dynamics between 2005 and 2009 was explored for the 25 tree species that presented 20 or more individuals as they correspond to representative populations in the sampled area [57]. Population biomass dynamics was explained in terms of mortality, growth, recruitment (or ingrowth) in biomass and richness of natural regeneration (in number of species) during the 4-year period.

Annual woody biomass was estimated for 2005 and 2009 using an allometric equation developed by Mugasha and Chamshama [58] for miombo woodlands with similar edaphic and climatic conditions ${ }^{\mathrm{a}}$ :

$$
W B=b 0 \times\left(d b h^{b 1}\right)
$$

Where, $\mathrm{WB}=$ woody biomass $\left(\mathrm{kg}\right.$ tree $\left.\mathrm{e}^{-1}\right) \mathrm{dbh}$ in $\mathrm{cm}$, $b_{1}=0.0625$ and $b_{0}=2.553$ corresponding to the regression coefficients.

Biomass of trees that died during the study period of 4 years was calculated using Eq. (3) from Marzoli [59]:

$$
D B=v o l \times(M D / A)
$$

Where: $D B=$ dead biomass (ton ha- ${ }^{1}$ ), vol = volume of the dead tree $\left(\mathrm{m}^{3}\right), M D=$ mean timber density for miombo species ( 0.65 for miombo woodlands of central and northern Mozambique) and $A=$ sampling area (3.55 ha).

Net biomass changes for each species were calculated using Eq. (4):

$$
\text { Net biomass change }=(\text { WB2009-WB2005 })-D B
$$

Where: WB2009 = woody biomass for the year 2009 (ton ha- $^{1}$ ), WB2005 = woody biomass for the year 2005 ( $\left(\right.$ ton ha- $\left.^{1}\right)$ and DB $=$ dead biomass (ton ha- $\left.{ }^{1}\right)$.

CSD for the miombo ecosystem in NNR was considered in this study as the carbon in the aboveground vegetation (woody, grass, herbaceous and litter) and superficial soil (30 $\mathrm{cm}$ depth). The biomass of all the vegetation components (live trees, dead vegetation, grasses, herbaceous and litter) was converted to carbon using the 0.5 conversion factor [60]. Soil carbon was estimated using Eq. (5) from Pearson et al. [44]:

$$
S C=B D \times D \times C \times 100
$$

Where: $S C=$ soil carbon content (ton ha- ${ }^{1}$ ), $B D=$ bulk density $\left(\mathrm{g} \mathrm{m}^{3}\right), \quad D=$ depth of soil sample collection $(30 \mathrm{~cm})$ and $C=\%$ carbon content estimated in the laboratory. Carbon estimation precision $(P)$ was estimated using Eq. (6) from Pearson et al. [44]:

$$
P=E / \mu
$$

Where: $E$ error of estimation calculated as $E=\sqrt{ }\left[\left(t^{2}\right) \times\right.$ $\left.\left.\left((\mathrm{N} \times \mathrm{s})^{2} / \mathrm{n}\right)-(\mathrm{N} \times \mathrm{s})^{2}\right)\right], \mu=$ mean carbon density (ton ha $\left.{ }^{-1}\right)$, $t=$ " $t$ " for $95 \%$ confidence interval $(=2), N=$ proportion of sampled area in relation to the total areas of NNR $\left(8.07 \times 10^{-7}\right), n=$ number of sampling plots (50), $s=$ standard deviation of the mean.

\section{Endnote}

${ }^{a}$ Eq. (1) was developed in the Kitulangalo forest in Morogoro, Tanzania under similar edaphic-climatic conditions as Niassa National Reserve. The site is dominated by open miombo woodland. The climate is tropical and sub humid within 700 and $1000 \mathrm{~mm}$ of mean annual precipitation and a mean annual temperature of $24.3^{\circ} \mathrm{C}$ [58].

\section{Abbreviations}

AGBC: Aboveground biomass and carbon; CSD: Carbon stock density; Dbh: Diameter-at-breast height; DPM: Disc pasture meter; GPS: Geographic positioning system; IPCC: Intergovernmental panel on climate change; IVI: Importance value index; MAP: Mean annual precipitation; MAT: Mean annual temperature; MRV: Monitoring, reporting and verification; NNR: Niassa national reserve; REDD+: Reducing emissions from deforestation and forest degradation. 


\section{Competing interests}

The authors declare they have no competing interests.

\section{Author' contributions}

NSR conceived the study, coordinated data collection, analysis and interpretation and the draft of the manuscript. CNM participated in data collection and analysis. IRM has been involved in data analysis, drafting the manuscript and revising it critically. RAWA has made substantial contributions to acquisition and interpretation of data and helped to draft the manuscript. AIR has made substantial contributions to data analysis and interpretation and co-coordinated the drafting of the manuscript. All authors read and approved the final manuscript.

\section{Authors' information}

NSR: Associate Professor at the Faculty of Agronomy and Forest Engineering since 2013 has been conducting research in the Niassa National Reserve since 2004. Her main research areas are carbon balance and effects of disturbances on miombo structure and composition. NSR is the coordinator of the Miombo Network of Southern Africa.

CNM: Masters student in Agrarian Development with emphasis in forest and fauna resources management. CNM is also working at the Ministry of tourism in Mozambique.

IRM: Senior Researcher at the Tropical Botanical Garden, Tropical Research Institute (IICT), Portugal. Main research focus, biodiversity conservation. Since 2007 she has been collaborating with NSR in the study of biodiversity, fire and carbon dynamics in the Niassa National Reserve.

RAWA: Assistant Professor at the Department of Geography, the University of Tennessee. Research Interests: applied science problems to provide solutions to questions concerning possible land degradation, climate change, invasive species, conservation biology, and ecological restoration.

AIR: Senior Researcher with Habilitation and Deputy Director of Biotrop Environment, Agriculture and Development Center, Tropical Research Institute (IICT), Portugal. Main research focus: genetic resources, biodiversity and plant-environment interactions. Since 2007 she has been collaborating with NSR in the study of biodiversity, fire and carbon dynamics in the Niassa National Reserve.

\section{Acknowledgments}

The authors would like to thank the Sociedade para a Gestão e Desenvolvimento da Reserva do Niassa (SGDRN), especially Mrs. Anabela Rodrigues and Mr. Madyo Couto; the funding sources: Fundo Nacional de Investigação (FNI), Research Fund of Eduardo Mondlane University, Mozambique and RUFORUM; Start Up Funds from the Department of Ecosystem Science \& Management, \& Texas Agrilife Research, Texas A\&M University, College Station, TX; and the field work team: Mrs. Cândida Zita, Mrs Isménia Amaral, Mr. Aires Banze, Mrs. Gisella Guambe, Mr. Rafael Lima and Mr. Paulo Chaleta. Acknowledges are also due to Prof. Robert Voeks, California State University, who kindly accepted to review the English.

\section{Author details}

1 Department of Forest Engineering, Eduardo Mondlane University, P.O. Box 257, Maputo, Mozambique. ${ }^{2}$ Agrobiodiversity Unit, Tropical Research Institute, Quinta do Marquês, Oeiras 2784-505, Portugal. ${ }^{3}$ Department of Geography, University of Tennessee, Burchfiel Geography Building, 1000 Phillip Fulmer Way, Knoxville TN37996-0925, USA. ${ }^{\circ}$ Department of Ecosystem Science \& Management, Texas A\&M University, TAMU 2138, College Station, TX 77843-2138, USA.

Received: 5 July 2013 Accepted: 6 November 2013

Published: 9 November 2013

\section{References}

1. Asner GP, Martin RE, Knapp DE, Tupayachi R, Anderson C, Carranza L, Martinez P, Houcheime M, Sinca F, Weiss P: Spectroscopy of canopy chemicals in humid tropical forests. Remote Sens Environ 2011 115(12):3587-3598.

2. Eggleston S, Buendia L, Miwa K, Ngara T, Tanabe K: IPCC quidelines for National Greenhouse Gas Inventories. Hayama, Japan: IPCC-IGES; 2006.

3. Gibbs HK, Brown S, Niles JO, Foley JA: Monitoring and estimating tropical forest carbon stocks: making REDD a reality. Environ Res Lett 2007, 2:1-13.
4. GOFC-GOLD (Global Observation of Forest and Land Cover Dynamics): Reducing greenhouse gas emissions from deforestation and degradation in developing countries: a sourcebook of methods and procedures for monitoring, measuring and reporting. Edmonton, Canada: GOFC-GOLD; 2008.

5. Schimel DS: Drylands in the earth system. Science 2010, 327:418-419.

6. Grace J, San José J, Meir P, Miranda HS, Montes RA: Productivity and carbon fluxes of tropical savannas. J Biogeogr 2006, 33:387-400.

7. Munishi PKT, Mringi S, Shirima DD, Linda SK: The role of the miombo woodlands of the southern highlands of Tanzania as carbon sinks. J Ecol Nat Environ 2010, 2(12):261-269.

8. Ribeiro NS, Shugart HH, Washington-Allen RA: The effects of fire and elephants on species composition and structure of the Niassa Reserve, northern Mozambique. For Ecol Manage 2008, 255:1626-1636.

9. Williams M, Ryan CM, Rees RM, Sambane E, Fernando J, Grace J: Carbon sequestration and biodiversity of re-growing Miombo woodlands in Mozambique. For Ecol Manage 2008, 254:145-155.

10. Rotenberg E, Yakir D: Contribution of semi-arid forests to the climate system. Science 2010, 327:451-454. http://dx.doi.org/10.1126/science.1179998.

11. Dewees PA, Campbell BM, Katerere $Y$, Sitoe A, Cunningham AB, Angelsen A, Wunder S: Managing the miombo woodlands of Southern Africa: policies, incentives and options for the rural poor. $J$ Nat Resour Policy Res 2010, 2:57-73. http://dx.doi.org/10.1080/19390450903350846.

12. Frost P: The ecology of Miombo Woodlands. In The Miombo in Transition: Woodlands and Welfare in Africa. Edited by Campbell B. Bogor: CIFOR; 1996:11-55.

13. Belsky AJ, Amundson RG, Duxbury JM, Riha SJ, Ali AR, Mwonga SM: The effects of trees on their physical, chemical, and biological environments in a semi-arid savanna in Kenya. J App Ecol 1989, 26:1005-1024.

14. Dean WRJ, Milton SJ, Jeltsch F: Large trees, fertile islands, and birds in arid savanna. J Arid Environ 1999, 41(1):61-78.

15. Treydte AC, Looringh van Beeck F, Ludwig F, Heitkönig IMA: Improved beneath-crown grass quality in South African savannas varying locally and over season. J Veg Sci 2008, 19:663-670.

16. Hairiah K, Sitompul SM, van Noordwijk M, Palm CA, ASB Lecture Note 4B, ICRAF, SEA Regional Research Programme: Methods for sampling carbon stocks above and below ground. Bogor, Indonesia: ICRAF; 2001. http://www asb.cgiar.org/PDFwebdocs/LectureNotes/ASB-LN-4B-Hairiah-et-al-2001Methods-sampling-carbon-stocks.pdf.

17. Archibald S, Bond WJ, Stock WD, Fairbanks DHK: Shaping the landscape: fire-grazer interactions in an African savanna. Ecol Appl 2005, 15(1):96-109.

18. Desanker PVF, Frost PGH, Justice CO, Scholes RJ: The Miombo Network: Framework for a Terrestrial Transect Study of Land-Use and Land-Cover Change in the Miombo Ecosystems of Central Africa. Stockholm: IGBP Report 41; 1997.

19. Ribeiro NS, Saatchi SS, Shugart HH, Washington-Allen RA: Aboveground biomass and leaf area index (LAl) mapping for Niassa Reserve, northern Mozambique. J Geophys Res 2008, 113:G02S02. http://dx.doi:10.1029/2007JG000550.

20. Sankaran M, Hanan NP, Scholes RJ, Ratnam J, Augustine D, Cade BS, Gignoux J, Higgins SI, Le Roux X, Ludwig F, Ardo J, Banyikwa F, Bronn A, Bucini G, Caylor KK, Coughenour MB, Diouf A, Ekaya W, Feral CJ, February EC, Frost PGH, Hiernaux P, Hrabar H, Metzeger KL, Prins HH, Ringrose S, Sea W, Tews J, Worden J, Zambatis N: Determinants of woody cover in African savannas. Nature 2005, 438(8):846-884.

21. Bond WJ, Midgley GF, Woodward Fl: What controls South African vegetation - climate or fire? S Afr J Bot 2003, 69(1):79-91.

22. Druce HC, Pretorius K, Slotow R: The response of an elephant population to conservation area expansion: phinda private game reserve, south Africa. Biol Conserv 2008, 141(12):3127-3138.

23. Owen-Smith N, Kerley GIH, Page B, Slotow R, van Aarde RJ: A scientific perspective on the management of elephants in the Kruger national park and elsewhere. S Afr J Sci 2006, 102:389-394

24. Maquia I, Ribeiro NS, Silva V, Bessa F, Goulao LF: Genetic diversity of brachystegia boehmii taub. And burkea Africana hook. f. Across a fire gradient in niassa national reserve, northern Mozambique. Biochem Systemat Ecol 2013, 2722:1-10.

25. SGDRN: Plano de Maneio da Reserva Nacional do Niassa 2006-2011. Maputo: SGDRN; 2007.

26. Leo-Smith K, Balson EW, Abacar A, Niassa Game Reserve: Management and Development Plan 1997-2006, vols. I \& II. Maputo: Direçcão Nacional de Florestas e Fauna Bravia, Ministério da Agricultura; 1997.

27. Ribeiro $\mathrm{N}$ : Interactions between fires and elephants in relation to vegetation composition and structure of miombo wooldands in northern Mozambique, PhD thesis. Charlottesville, Va: University of Virginia; 2007. 
28. Backéus I, Petterson B, Strömquist L, Ruffo C: Tree communities and structural dynamics in miombo (Brachystegia_Julbernardia) woodland, Tanzania. For Ecol Manage 2006, 230:171-178.

29. Boaler SB, Sciwale KC: Ecology of a miombo site, Lupa North Forest Reserve, Tanzania. II. Plant communities and seasonal variation in the vegetation. J Ecol 1966, 54:465-479.

30. Campbell BM, Cunliffe RN, Gambiza J: Vegetation structure and small-scale pattern in miombo woodland, Marondera. Bothalia 1995, 25:121-126.

31. Chidumayo EN: Structural differentiation of contiguous savanna woodland types in Zambia. Geo Eco Trop 1985, 9:51-66.

32. Guy PR: Changes in the biomass and productivity of woodlands in the sengwa wildlife research area Zimbabwe. J App/ Ecol 1981, 18(2):507-519.

33. Malaisse FP: The miombo ecosystem. In Tropical Forest Ecosystems, a state of knowledge report prepared by UNESCO/UNEP/FAO. Paris: UNESCO. Nat Resour Res 1978, 14:589-606.

34. Strang RM: Some man-made changes in successional trends on the Rhodesian highveld. J Appl Ecol 1974, 111:249-263.

35. Trapnell CG: Ecological results of woodland burning experiments in northern Rhodesia. J Ecol 1959, 47:129-168.

36. Ward HK, Clerghorn WB: The effect of ring-barking trees in Brachystegia Woodlands on the yield of Veld grasses. Rhodesia Agri J 1964, 61:98-107.

37. Zahabu E: Sinks and sources: a strategy to involve forest communities in Tanzania in global climate policy, PhD thesis. Twente: University of Twente; 2008

38. Campbell BM, Angelsen A, Cunningham A, Katerere Y, Sitoe A, Wunder S: Miombo woodlands - Opportunities and barriers to sustainable forest management. Bogor: CIFOR; 2007. http://www.cifor.org/miombo/docs/ Campbell_BarriersandOpportunities.pdf.

39. Kusaga MM: Participatory forest carbon assessment in Angai village land forest reserve in liwale district, Lindi region, Tanzania, Master thesis. Morogoro: Sokoine University of Agriculture; 2010.

40. Timberlake J, Golding JS, Clarke PG: Niassa Botanical Expedition June 2003: Report prepared for Sociedade para a Gestão e Desenvolvimento da Reserva do Niassa. Bulawayo: Bioversity Foundation for Africa; 2003.

41. Chidumayo EN: Early post-felling response of Marquesia woodland to burning in the Zambian Copperbelt. J Ecol 1989, 77:430-438.

42. Shirima DD, Munishi PKT, Lewis SL, Burgess ND, Marshall AR, Balmford A, Swetnam RD, Zahabu EM: Carbon storage, structure and composition of miombo woodlands in Tanzania's eastern Arc mountains. Afr J Ecol 2011 49:332-342.

43. IPCC: Forest Land. In Good practice guidance on land use, land-use change and forestry. Edited by Penman J, Gytarsky M, Hiraishi T, Krug T, Kruger D, Pipatti R, Buendia L, Miwa K, Ngara T, Tanabe K, Wagner F. Hayama, Japan: IPCC/IGES; 2003

44. Pearson T, Walker S, Brown S: Sourcebook for land use, land-use change and forestry projects. Washington DC: Winrock International and the BioCarbon Fund of the World Bank; 2005.

45. Sitoe A: Baseline carbon estimation in Dombe, Manica Biofuel production area. Maputo: Eduardo Mondlane University, GRNB- Faculty of Agronomy and Forestry Engineering; 2009

46. Tchaúque FDL: Avaliação da biomassa lenhosa aérea no Corredor da Beira Thesis. Maputo: Eduardo Mondlane University; 2004.

47. Scholes B: Miombo woodlands and global change (Box 2.2). In The Miombo in Transition: Woodlands and Welfare in Africa. Edited by Campbell B. Bogor: CIFOR; 1996:13.

48. Walker S, Desanker P: The impact of land use on soil carbon in Miombo Woodlands of Malawi. For Ecol Manag 2004, 203(1/3):345-360.

49. WWF SARPO (World Wildlife Fund Southern Africa Regional Office): A Planning Framework for the Management of Niassa Reserve: Report. Harare: WWF; 2002

50. WWF SARPO (World Wildlife Fund Southern Africa Regional Office): Conserving the Miombo Ecoregion: Reconnaissance Summary. Harare: WWF; 2002.

51. White F: Vegetation of Africa - a descriptive memoir to accompany the UNESCO/AETFAT/UNSO vegetation map of Africa: Natural Resources Research Report XX. Paris: UNESCO; 1983

52. Palgrave C: Trees of Southern Africa. Cape Town: Struik Publishers; 2002

53. de Koning J: Checklist of Vernacular Plant Names in Mozambique. Wageningen: Wageningen Agricultural University; 1993

54. Bransby DI, Tainton NM: The disc pasture meter. Possible applications in grazing management. Proc Grass/ Soc South Afr 1977, 5:115-118.
55. McKenzie N, Ryan P, Fogarty P, Wood J: Sampling, measurement and analytical protocols for carbon estimation in soil litter and coarse woody debris, National Carbon Accounting System: Technical Report 14. Canberra: Australian Greenhouse Office; 2000.

56. Lamprecht H: Silvicultura nos Trópicos. Eschborn: GTZ; 1990.

57. Chagas RK, Oliveira-Filho T, van den Berg E, Scolforo JRS: Dinâmica de populações arbóreas em um fragmento de floresta estacional semidecidual montana de Lavras, Minas Gerais. R Árvore, Viçosa-MG 2001, 25(1):39-57.

58. Mugasha AG, Chamshama SAO: Tree biomass and volume estimation for miombo woodlands at Kitulangalo, Morogoro, Tanzania, Indicators and Tools for Restoration and Sustainable Management of Forests in East Africa. Freiburg: I-TOO Working Paper 9; 2002.

59. Marzoli A: Avaliação Integrada das Florestas de Moçambique, Inventário Florestal Nacional. Maputo: Direcção Nacional de Florestas e Terras; 2007.

60. IPCC: Climate Change 2007: Synthesis Report. In Contribution of Working Groups I, II and III to the Fourth Assessment Report of the Intergovernmental Panel on Climate Change. Edited by Pachauri RK, Reisinger A. Geneva: IPCC; 2007.

doi:10.1186/1750-0680-8-11

Cite this article as: Ribeiro et al: Monitoring vegetation dynamics and carbon stock density in miombo woodlands. Carbon Balance and Management 2013 8:11.

\section{Submit your next manuscript to BioMed Central and take full advantage of:}

- Convenient online submission

- Thorough peer review

- No space constraints or color figure charges

- Immediate publication on acceptance

- Inclusion in PubMed, CAS, Scopus and Google Scholar

- Research which is freely available for redistribution

Submit your manuscript at www.biomedcentral.com/submit
C) Biomed Central 